\title{
Ground-level ozone and its potential impacts on human health in the Czech Republic
}

\author{
I. Hůnová, H. Livorová \& J. Ostatnická \\ Czech Hydrometeorological Institute (ČHMÚ), Prague, Czech Republic
}

\begin{abstract}
The elevated ground-level ozone concentrations are considered to be a risk factor for human health. In the Czech Republic the nation-wide ground-level ozone monitoring network was established in 1991 and at present it includes 60 monitoring sites representing rural, mountainous and town areas. This paper reports the results of data analysis of 30 min mean concentrations for period of 1995-1998. Exposure index AOT60 is calculated for monitoring sites. Fields of cumulative exposure prepared using the geographical information system ARC/INFO and its module GRID are presented. The percentual share of population and area of the country exposed to elevated AOT60 values are presented for different years under review.

For the period under review the highest ground-level ozone concentrations observed and exposures calculated are in 1995. The lowest concentrations and exposures are in 1997. The results reveal big differences among the years due to meteorological conditions. Distinct fact to be stressed is that even in the year with meteorological conditions extremely unfavourable for ozone formation (as 1997), the mean 8-h concentration of $60 \mathrm{ppb}$ (WHO guideline value for ozone) is exceeded considerably.

AOT60 values can be used as an indicator of ground-level ozone potential risk for human population. Other factors, nevertheless, are also to be taken into account.
\end{abstract}

\section{Introduction}

The elevated ground-level ozone concentrations are considered to be a risk factor both for human health and ecosystems. Ozone is not directly emitted but is a 
secondary pollution component formed in the atmosphere from precursors in photochemical reactions. Increasing man-made emissions of ozone precursors (nitrogen oxides, $\mathrm{NO}_{\mathrm{x}}$ and volatile organic compounds, VOCs) have led to increased photochemical production of ozone in the troposphere. Motor vehicles account for a considerable fraction of the total emissions of $\mathrm{NO}_{x}$ and VOCs to the atmosphere in Europe.

WHO and its European centre for environment and health revised the ambient air quality guidelines for human health protection [1] due to the latest scientific knowledge. Negative impacts on human health in case of ambient air quality guidelines for ozone exceedence are described [2]. Both monitoring and modeling results indicate that significant share of European population is exposed to ground-level ozone concentrations higher that these set up by ambient air quality guidelines.

There is no clear evidence what parameter is best suitable for assessment of ground-level ozone impact on human health. One possibility is to use e.g. the number of days with exceedence of mean 8-h concentration of $60 \mathrm{ppb}$ (WHO guideline value for ozone). This parameter, however, does not consider the differences in levels above $60 \mathrm{ppb}$. Another possibility is the calculation of defined statistical characteristics as 8 -h concentration given as $98^{\text {th }}$ percentile. This, however does not consider the frequency of exceedence [3]. Analogically with exposure index AOT 40 (Accumulated Exposure over Threshold of $40 \mathrm{ppb}$ ) used for assessment of ground-level ozone potential impact on vegetation and ecosystems, the exposure index AOT60 giving the cumulative exposure above $60 \mathrm{ppb}$ can be considered a suitable indicator. This index is calculated as sum of differences between recorded 8-h mean concentration and threshold value of 60 $\mathrm{ppb}$ for daylight hours for period of at least 6 months to include as much ozone episodes as possible [3].

In the Czech Republic, after an unprecedented decrease of $\mathrm{SO}_{2}$ concentrations due to severe legislative and technical measures (based on introduction of desulphurization units in the largest brown coal power plants and using gas and electricity for local heating systems), the ground-level ozone, together with particulate and $\mathrm{NO}_{\mathrm{x}}$ from ever increasing traffic, has been recognised as one of principal ambient air pollutants in recent decade. The nation-wide ground-level ozone monitoring network was established in 1991 and at present it includes 60 monitoring sites representing rural, mountainous and town areas. The automated measuring stations using the ultraviolet absorption photometry record 30 minute mean concentrations. Within the framework of annual ambient air quality review also the assessment of measured ozone data with respect to exceedence of limit values is provided and published [4]. The potential impact of ground-level ozone on forests and crops in the Czech Republic is estimated, results have been published $[5,6,7]$.

The data analysis for ground-level ozone as to its risk for human health has been carried out. The geographic information system ARC/INFO maps presenting the ground-level ozone limit value exceedences over the territory of the Czech Republic for period of 1995-1998 form the core of this paper. The 
ozone exposure fields are combined with population numbers indicating the potential risk for country's population.

\section{Methods}

For estimation of potential ground-level ozone impact on human health in the Czech Republic the data from central database ISKO (Ambient Air Quality Information System) operated by the Czech Hydrometeorological Institute are used.

The 30 min mean concentrations from monitoring sites for 1995-1998 have been analysed. Cumulative exposure index AOT60 at monitoring sites is calculated according the equation (1).

$$
\text { AOT60 }=\sum_{i \in R} \sum_{j=1}^{n} \sum_{k \in C}\left(c_{i j k}-p\right),
$$

where

$c_{i j k}$ means ground-level ozone concentration $\geq 60 \mathrm{ppb}$ measured in the $i$-th month, $j$-th day and $k$-th hour,

$p \quad$ means threshold concentration of $60 \mathrm{ppb}$,

$R$ is a set of month in a calendar year,

$C$ is a set of all hours of a day,

$n \quad$ is a number of days in a month.

AOT60 $=0 \mathrm{ppb} . \mathrm{h}$ is mathematically equivalent to zero exceedence of the WHO guideline of $120 \mu \mathrm{g} \cdot \mathrm{m}^{-3}(60 \mathrm{ppb})$.

ARC/INFO and its module GRID is used for preparing exposure fields. The fields of cumulative exposure values are carried out by interpolation method of krigging in $500 \mathrm{~m} \times 500 \mathrm{~m}$ grid. For presentation these are visualised in grid of $5 \mathrm{~km} \times 5 \mathrm{~km}$.

\section{Results}

The fields of AOT60 values for 1995-1998 are presented at Fig. 1-4. Exposure values above the threshold of AOT60 $=0 \mathrm{ppb}$.h are classified into 9 categories: with cumulative exposure $\leq 1000,(1000-1500>,(1500-2000>,(2000-2500>$, $(2500-3000>,(3000-4000>,(4000-5000>,(5000-6000>,>6000$.

The Tab. 1 presents percentual share of population and area in respective category for different years. 


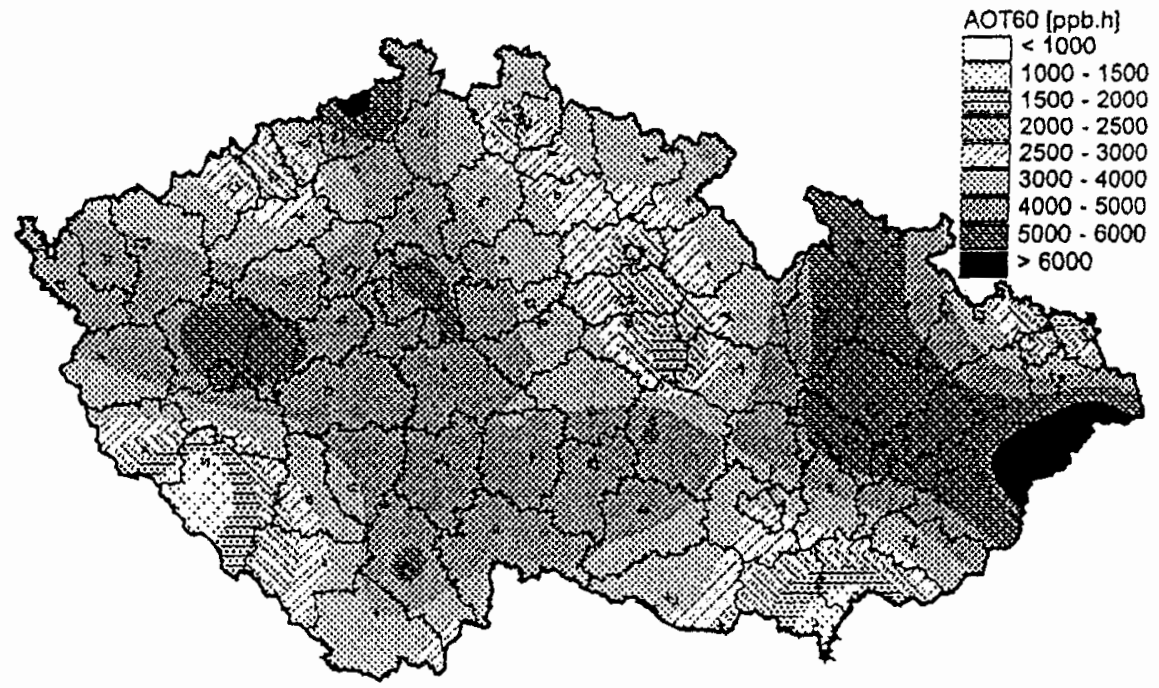

Figure 1: Fields of exposure index AOT60 values, the Czech Republic, 1995

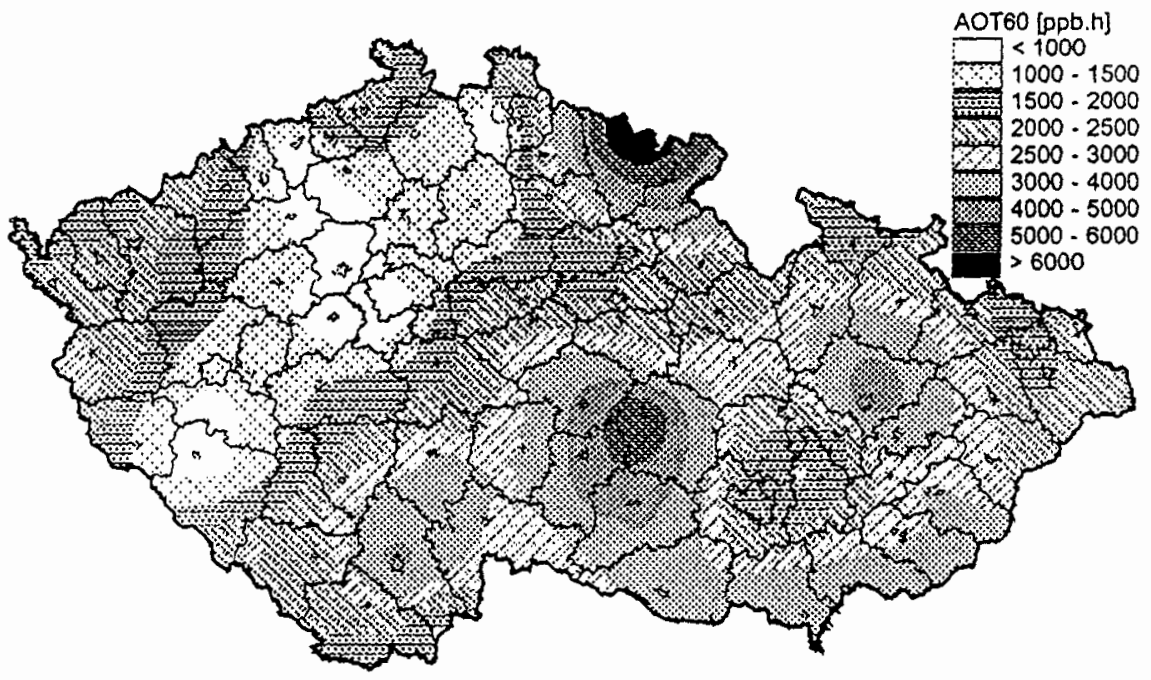

Figure 2: Fields of exposure index AOT60 values, the Czech Republic, 1996 


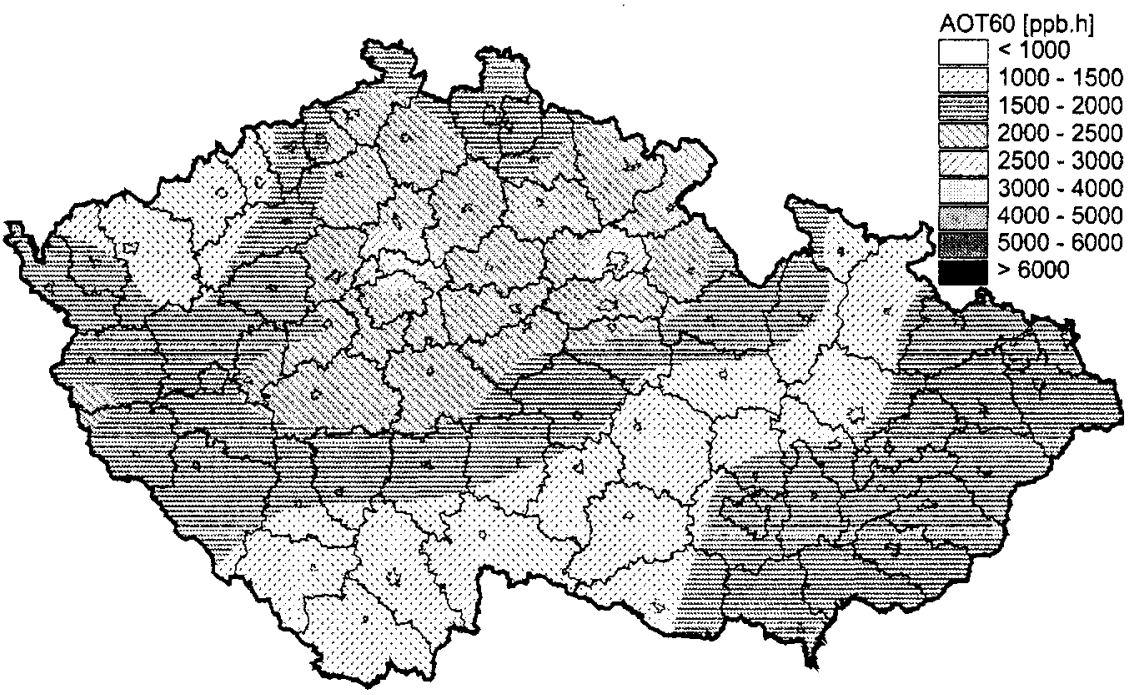

Figure 3: Fields of exposure index AOT60 values, the Czech Republic, 1997

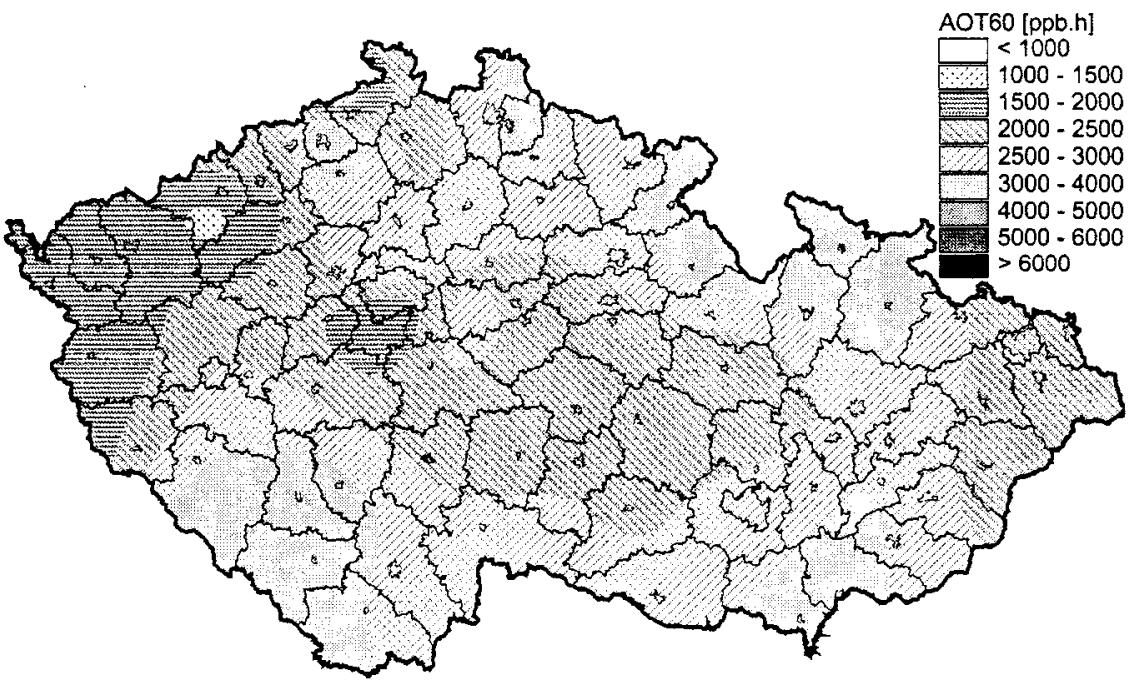

Figure 4: Fields of exposure index AOT60 values, the Czech Republic, 1998 
Table 1: Percentual share of population and area of the Czech Republic categorized by cumulative exposure AOT60 values in the period of 1995-1998

\begin{tabular}{|c|c|c|c|c|c|c|c|c|}
\hline \multirow[b]{2}{*}{ 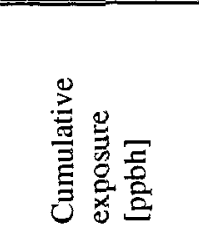 } & \multicolumn{2}{|c|}{1995} & \multicolumn{2}{|c|}{1996} & \multicolumn{2}{|c|}{1997} & \multicolumn{2}{|c|}{1998} \\
\hline & 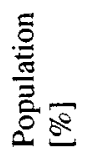 & 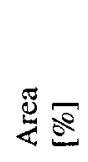 & 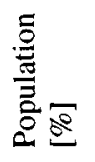 & $\stackrel{5}{5}$ & 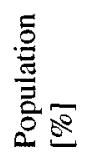 & $\stackrel{\mathbb{E}}{\bar{E}}$ & 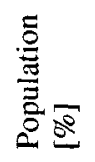 & $\frac{8}{2} \bar{g}$ \\
\hline$\leq 1000$ & 0,06 & 0,02 & 5,79 & 14,05 & 0,07 & 0 & 0 & 0 \\
\hline$(1000-1500>$ & 1,56 & 1,23 & 13,74 & 16,97 & 28,94 & 17,92 & 0,29 & 0,20 \\
\hline$(1500-2000>$ & 2,59 & 2,36 & 17,38 & 19,00 & 47,05 & 49,17 & 10,32 & 8,79 \\
\hline$(2000-2500>$ & 6,33 & 9,17 & 23,41 & 19,85 & 22,04 & 25,54 & 34,15 & 40,50 \\
\hline$(2500-3000>$ & 10,45 & 13,58 & 15,37 & 10,96 & 1,90 & 7,37 & 38,35 & 39,45 \\
\hline$(3000-4000>$ & 26,63 & 19,78 & 17,88 & 12,08 & 0 & 0 & 16,89 & 11,06 \\
\hline$(4000-5000>$ & 37,03 & 30,98 & 4,30 & 5,65 & 0 & 0 & 0 & 0 \\
\hline$(5000-6000>$ & 13,77 & 21,84 & 1,69 & 1,00 & 0 & 0 & 0 & 0 \\
\hline$>6000$ & 1,58 & 1,04 & 0,44 & 0,44 & 0 & 0 & 0 & 0 \\
\hline
\end{tabular}

\section{Discussion}

The monitoring network is composed not only by city stations but also by rural and mountain sites which makes it less suitable for assessing human exposure. Nevertheless data from all stations are included into analysis in order to have enough data for interpolation and construction of exposure fields.

Different AOT60 values and percentual shares of population and area in cumulative exposure categories in different years under review corresponds with different meteorological conditions over the territory of the Czech Republic in respective years.

The results of data analysis indicate that the highest potential risk for human health due to elevated ground-level ozone concentrations for the period under review occurred in 1995. This year is characterised by meteorological conditions favourable for ground-level ozone formation (sunny, hot weather). This resulted in relatively long-term episodes lasting as long as 3 weeks with high frequency of limit value exceedences.

The year with the least potential for ground-level ozone formation was 1997. This year's summer was very untypical with low sun radiation and low temperatures. No episodes of elevated ozone concentrations have been recorded.

The AOT60 fields presented indicate areas and population within the country which can be negatively impacted due to elevated ground-level ozone concentrations. Nevertheless risk assessment analysis requires also other factors, which can influence sensitivity of humans towards the ozone exposure to be 
taken into account. As the most important physical load (physical training, manual work), illness, age, sex, ethnicum/race, smoking habit and environmental factors are identified [8].

\section{Conclusions}

Maps with AOT60 exposure fields represent an important tool for risk assessment analysis. They can serve as a supporting material for indication of areas within the country where population is endangered due to elevated groundlevel ozone exposures.

The data analysis of ground-level ozone concentrations monitored over the territory of the Czech Republic during 1995-1998 indicate that this ambient air pollutant represents a serious potential risk for human health. This means a real problem as due to the nature of this secondary pollutant it is very difficult to adopt appropriate measures resulting in decreasing of ambient air quality levels substantially.

\section{References}

[1] Air Quality Guidelines for Europe, WHO: Copenhagen, 1987.

[2] Update and revision of the air quality guidelines for Europe, WHO Regional office for Europe: Copenhagen, 1995.

[3] Simpson, D., Modeled ozone concentrations in relation to health issues. Workshop on Health effects of ozone and nitrogen oxides in an integrated assessment of air pollution. MRC/IEH: Eastbourne, 1996.

[4] Fiala, J. \& Ostatnická, J., (eds.). Znečištění ovzduší na území České republiky v roce 1999/Air pollution in the Czech Republic in 1999. ČHMÚ: Prague, 2000.

[5] Hůnová, I., Livorová, H. \& Ostatnická, J., Critical Levels for Ozone in the Czech Republic. Meteorologický časopis/Meteorological Journal SHMÚ 3 (1), pp. 11-18, 2000.

[6] Hůnová, I., Livorová, H., Uhlírová, H. \& Ostatnická J., Ground-level ozone and its potential impacts on forests in the Czech Republic. Proc. of the $9^{\text {th }}$ Int. Conf. Transports et Pollution de l'Air, ed. R. Joumard, INRETS \& TUG: Arcueil, pp. 357-362, 2000.

[7] Hůnová, I., Livorová, H., Ostanická, J. \& Uhlírová, H., Přízemní ozon a jeho potenciální vliv na lesy v České republice/ Ground-level ozone and its potential impacts on forests in the Czech Republic (bilingual: Czech/English). Monitoring zdravotního stavu lesa v České republice/ Forest Condition Monitoring in the Czech Republic, ed. H. Uhlírová, VÚLHM: Praha, pp. 33-37, 2000.

[8] Rombout, P. J. A. \& Schwarze, P. E., Quantitative exposure-response relationships for ozone. Workshop on Health effects of ozone and nitrogen oxides in an integrated assessment of air pollution. MRC/IEH: Eastbourne, 1996. 